\title{
Sepsis Biomarkers in Neonates and Children: C-Reactive Protein and Procalcitonin
}

\author{
J. Markic ${ }^{1,2}$ \\ M. Saraga ${ }^{1,2}$ \\ P. Dahlem ${ }^{3}$ \\ 1 University of Split School of Medicine, Split, Croatia \\ ${ }^{2}$ Department of Pediatrics, University Hospital of Split, Split, Croatia \\ ${ }^{3}$ Department of Pediatrics, Medical Center Coburg, Academic \\ Hospital of the University of Split, Coburg, Germany \\ J Child Sci 2017;7:e89-e95.
}

\begin{abstract}
Address for correspondence J. Markic, MD, PhD, Department of Pediatrics, University Hospital of Split, Spinciceva 1, 21000 Split, Croatia (e-mail: josko.markic@gmail.com).
\end{abstract}

\begin{abstract}
Keywords

- sepsis

- biomarker

- C-reactive protein

- procalcitonin

Bacteremia and sepsis are still significant causes of morbidity and mortality among children and neonates worldwide. Early recognition of bacterial sepsis and initiation of therapy is associated with better treatment outcomes but is challenging as many of the early clinical features can be similar to those in self-limiting viral illnesses. Diagnosis of bacteremia is also challenging because the use of blood culture, the gold standard for diagnosis of bacteremia, is fraught with difficulties. Therefore, various biomarkers are of great importance in the process of diagnosis of sepsis and evaluation of its severity. They can indicate the presence or absence or severity of sepsis and are helpful in differentiating bacterial from viral and fungal infection. Of the many proposed biomarkers for infection and/or sepsis, acute-phase proteins such as C-reactive protein (CRP) and procalcitonin (PCT) are widely used and have perhaps been most widely assessed. In this review, we will present the advantages and disadvantages of CRP and PCT determination in sepsis evaluation. It will be presented that it is still not always possible to predict accurately the presence of bacterial infection on the basis of clinical appearance and available laboratory tests. Therefore, the investigation of new and better biomarkers is challenging and ongoing.
\end{abstract}

\section{Introduction}

Bacteremia and sepsis, along with other serious bacterial infections (SBIs), are still significant causes of morbidity and mortality among children worldwide despite the use of modern antibiotics and evidence-based resuscitation guidelines and treatments. ${ }^{1}$ Sepsis in neonates is a significant contributor to morbidity and mortality. Based on the onset, neonatal sepsis is classified into two major categories: early onset sepsis (EOS) and late onset sepsis. In the literature, however, there is little consensus as to what age limits apply, with EOS ranging from 48 hours to 6 days after delivery.
Early recognition of bacterial sepsis and initiation of therapy is associated with better treatment outcomes but is challenging as many of the early clinical features can be similar to those in self-limiting viral illnesses. ${ }^{2}$ In a study of more than 400 children with meningococcal sepsis in the United Kingdom, only half were referred to hospital at their first primary care consultation, usually after a delay of several hours following the first symptoms and/or signs of sepsis. ${ }^{3}$

Diagnosis of bacteremia is also challenging because the use of blood culture, the gold standard for diagnosis of bacteremia, is fraught with difficulties. First, incubation of bacteria may take several days (2-4 days). Second, genuine received

June 10, 2016 accepted after revision March 7, 2017
Issue Theme Pediatric Sepsis Biomarkers; Guest Editors: Peter Dahlem, MD, PhD, Marijan Saraga, MD, PhD, Walter L. Strohmaier, MD, PhD
Copyright @ 2017 Georg Thieme Verlag KG Stuttgart · New York

\section{License terms \\ ()(1) $\Theta \circledast$}


bacteremia may remain undetected in a significant proportion of infected cases because of the small volume of blood taken. Third, bacteremia in the neonate may often be transient or intermittent, especially during the early stages of infection. ${ }^{4}$ Also, if blood is drawn after administration of antibiotics, bacterial growth can be suppressed.

However, in the era of multidrug resistance, it is mandatory to avoid unnecessary use of antibiotics. Therefore, various biomarkers are of great importance in the process of diagnosis of sepsis and evaluation of its severity. They can indicate the presence or absence or severity of sepsis ${ }^{5,6}$ and are helpful in differentiating bacterial from viral and fungal infection. It remains difficult to differentiate sepsis from other noninfectious causes of systemic inflammatory response syndrome (SIRS), and there is a continuous search for better biomarkers of sepsis.

Based on the National Institutes of Health consensus conference in $2001,{ }^{5}$ a biomarker is broadly defined as a characteristic that can be measured objectively and evaluated as an indicator of normal biological processes, pathological processes, or pharmacological responses to a therapeutic intervention. There are four general types of biomarkers. ${ }^{6,7}$ Diagnostic biomarkers indicate the presence or absence of a disease process or other clinical condition. The majority of them are of most value within a specific clinical context and with the addition of adjunctive diagnostic tests. This class includes the subset of screening biomarkers. Monitoring biomarkers are the biomarkers whose levels change dynamically as a disease process evolves or in response to applied therapeutic interventions, affording the clinician the ability to track the course of disease and assess adequacy of treatment. Stratification biomarkers are useful to sort a population of patients into classes of severity. The purpose of these biomarkers is to help clinicians to apply therapeutic interventions to groups where the most benefit will be realized at the least risk and to optimize the risk-tobenefit ratio of a given therapy. Finally, surrogate biomarkers are used to predict outcome of a disease process rather than follow its course or to titrate therapy. Robust surrogate biomarkers need to be directly affected by a given therapy, reliably predict the outcome of interest, and be mechanistically linked to the biological processes that affect the outcome of interest.

Of the many proposed biomarkers for infection and/or sepsis, acute-phase proteins such as C-reactive protein (CRP) and procalcitonin (PCT) are widely used and have perhaps been most widely assessed. To be clinically useful, infection biomarker should have a well-defined cutoff value for differentiating infected from no infected patients, particular bacterial from viral infection, and be able to identify infected cases at an early stage. For diagnostic purposes, a very high sensitivity and negative predictive value (approaching 100\%), and good specificity and positive predictive value $(>85 \%)$ are desirable. ${ }^{4}$ Also, the kinetics of a biomarker should be considered along with its sensitivity and specificity because a rapid increase of the marker would allow a good discrimination between health and disease. It is very rare that a diagnostic biomarker is strictly present or absent. Much more commonly, the presence of a biomarker is measured as a continuous variable, and cutoffs are defined along that continuum to establish the presence or absence of disease. The sensitivity and specificity of a biomarker are dependent upon where those cutoffs are placed.

\section{C-Reactive Protein}

CRP is an acute-phase reactant found in the blood that is synthesized by the liver in response to the elevated levels of the cytokines (interleukin [IL]-1, IL-6, and tumor necrosis factor- $\alpha$ ). CRP is so named for its ability to precipitate from serum in the presence of pneumococcal cell wall C-polysaccharide. It is produced and becomes elevated within 4 to 6 hours after onset of tissue injury or inflammation; it doubles every 8 hours before peaking approximately 36 hours later. ${ }^{8,9}$ Due to this limitation for the early identification of infection within 24 hours of onset, serial measures of CRP are required for accurate detection of infection. ${ }^{10}$ Serial measures of CRP are also needed in identifying noninfected neonates and have been reported to have $99 \%$ negative predictive value. ${ }^{11}$

CRP is the most widely used biomarker in neonates. ${ }^{12-14}$ However, due to previously mentioned time delay in the response to infection, it is often combined with other serum biomarkers such as PCT or ILs. ${ }^{13,14}$ Philip and Mills recommended that at any neonatal age, a CRP value of $\geq 10 \mathrm{mg} / \mathrm{L}$ in the presence of one or more clinical signs or one or more risk factors for infection should alert the clinician to transfer a neonate to the intensive care unit and start antimicrobial therapy. ${ }^{15}$ They were also able to minimize antibiotic therapy using this clinical pathway for sepsis. Franz et al also considered a CRP value of $>10 \mathrm{mg} / \mathrm{L}$, in the presence of at least one clinical sign compatible with infection, as a criterion to make a diagnosis of clinical septicemia in neonates. ${ }^{13,16}$ However, some of the results of published studies on the use of CRP as a biomarker of neonatal sepsis are contradictory. Benitz et al calculated a receiver operating characteristic (ROC) curve for CRP levels in proven neonatal sepsis and showed poor sensitivity of CRP measurements 24 hours after initiation of antibiotic therapy. ${ }^{17}$

Pulliam et al reported the results of a prospective study in 2001 examining the utility of CRP in evaluating febrile children. ${ }^{18}$ Seventy-seven patients between 1 and 36 months of age were enrolled, all with fever $>39^{\circ} \mathrm{C}$. CRP was found to be a much more useful screening tool than white blood cell (WBC) counts and neutrophil count for this population of patients, with a sensitivity of $79 \%$ and a specificity of $91 \%$. The limitation of the study is that the number of enrolled young infants was small. In febrile infants up to 3 months old, Bilavsky et al, in 2009, also reported that CRP level is a valuable laboratory measure in assessment of the risk of SBI. ${ }^{19}$ They found that various cutoffs had a better sensitivity and specificity than WBC cutoffs. Their results showed that a CRP value of $>50 \mathrm{mg} / \mathrm{L}$ should alert the clinician to a high likelihood of SBI. ${ }^{19}$ Nevertheless, despite the high specificity of CRP, its sensitivity was low. The study by Olaciregui et al was focused on same age group and showed that CRP is 
useful in predicting SBI but should be used in conjunction with other markers. ${ }^{20}$

A study by Gendrel et al found that the mean CRP was $148.4,82.8$, and $19.5 \mathrm{mg} / \mathrm{L}$, respectively, for patients divided into three groups: invasive bacterial infection, noninvasive bacterial infection, and viral infection. ${ }^{21}$ As an indicator of bacterial from viral infection, the authors were able to achieve a sensitivity of $98 \%$ using CRP alone. However, the cutoff used to distinguish between viral and bacterial infection was $10 \mathrm{mg} / \mathrm{L}$, the lowest proposed cutoff. Notably, this cutoff is well below the mean CRP for viral infections $(19.5 \mathrm{mg} / \mathrm{L})$. Not surprisingly, Gendrel et al had the lowest CRP specificity (50\%).

Although CRP has been used for many years in pediatrics, its specificity and diagnostic accuracy has been questioned. ${ }^{22,23}$ The results by Sanders et al, reported in a review article in 2008, indicate that CRP is of moderate value for ruling out SBI in a child with a fever but is of limited value for ruling out all bacterial infections. ${ }^{24}$ The diagnostic accuracy of the test for all bacterial infections is limited by the significant overlap in CRP values for children with viral and bacterial infections.

\section{Procalcitonin}

PCT is a 116-amino-acid precursor peptide for the hormone calcitonin, with a molecular weight of $13 \mathrm{kDa}$, which is produced in the thyroid gland to regulate serum calcium concentrations. No disorders attributable to either an excess or a deficiency of calcitonin have been identified. All tissues in the body have the capacity to produce PCT, but only the thyroid $\mathrm{C}$ cells express the appropriate enzymes that cleave the prohormone into mature calcitonin. ${ }^{25}$ Under normal conditions, the thyroid gland (thyroid parafollicular or clear cells) is the only tissue that produces PCT and serum levels are very low. It has been reported in many interventional trials that a low PCT indicates the absence of a need for antimicrobial therapy. ${ }^{26-29}$

Most microbial infections induce a ubiquitous upregulation in CALC1 gene expression on chromosome 11 and a subsequent release of PCT from nearly all tissues and cell types throughout the body (including the liver, spleen, and adipose tissue). ${ }^{30}$ In bacterial infections, PCT increases from concentrations in the picogram range (below the detection level of current PCT assays) to concentrations ranging from 1 to $1,000 \mathrm{ng} / \mathrm{mL}$. PCT begins to rise at 4 hours after the onset of systemic infection or exposure to bacterial endotoxin, peaks at 6 to 8 hours, and remains elevated for at least 24 hours. $^{31}$ This increase often correlates with the severity of the disease and with mortality. ${ }^{32-35}$ Therefore, PCT is used as a diagnostic marker of bacterial infection. It can help to determine the progression of infection to sepsis and septic shock and to assess responsiveness to treatment serving as a prognostic indicator.

Elevations in PCT are generally observed more rapidly before CRP rises, and the peak value is achieved within a much shorter time frame. Additionally, when the patient responds appropriately to therapy, PCT may serve as mon- itoring biomarker since its levels return to normal much quicker than those of CRP. ${ }^{36,37}$ Serial measurement of PCT levels has therefore been used to direct and limit antibiotic usage. The purpose of that is to reduce both bacterial antibiotic resistance and patient-centered side effects such as nephrotoxicity and drug reactions. Stocker et al found a significant difference in the proportion of newborns treated with antibiotics $\geq 72$ hours between the standard group (82\%) and the PCT group (55\%). ${ }^{38}$ On average, PCT-guided decision-making resulted in a shortening of 22.4 hours of antibiotic therapy. However, PCT value has also been challenged. ${ }^{31}$

There is some controversy surrounding the use of PCT in the diagnosis of sepsis in neonates, both term and premature ones. Several investigators advocate PCT as a good diagnostic biomarker of sepsis demonstrating better performance than CRP, whereas others have not found significant difference. ${ }^{39-41}$ Some groups of authors emphasize lack of specificity of PCT in this age group. A significant reason for this has its roots in perinatal PCT kinetics where various researchers have demonstrated a normal, physiological increase in serum PCT levels of healthy neonates that peaks at approximately 24 to 48 hours of life (mean: $1.5-2.5 \mathrm{ng} / \mathrm{mL}$; range $0.1-20 \mathrm{ng} / \mathrm{mL}$ ) and returns to normal on approximately the third day of life. ${ }^{42,43}$ Also, infants with respiratory distress syndrome, hemodynamic failure, perinatal asphyxia, intracranial hemorrhage, pneumothorax, or after resuscitation have raised serum PCT concentrations that do not differ from those of septic neonates up to 48 hours after onset of clinical signs of distress or infection. ${ }^{44,45}$ Therefore, Stocker et al published the normal age-adapted PCT ranges (-Fig. 1). ${ }^{38}$

Maniaci et al demonstrated in febrile infants $<90$ days old that PCT is a useful marker for SBI in young febrile infants. ${ }^{46}$ The area under the curve (AUC) of the ROC was 0.76 for definite and possible SBI, that is, better than that of WBC or neutrophil count. The optimal cutoff value used was $0.12 \mathrm{ng} / \mathrm{mL}$, lower than in other studies with a sensitivity

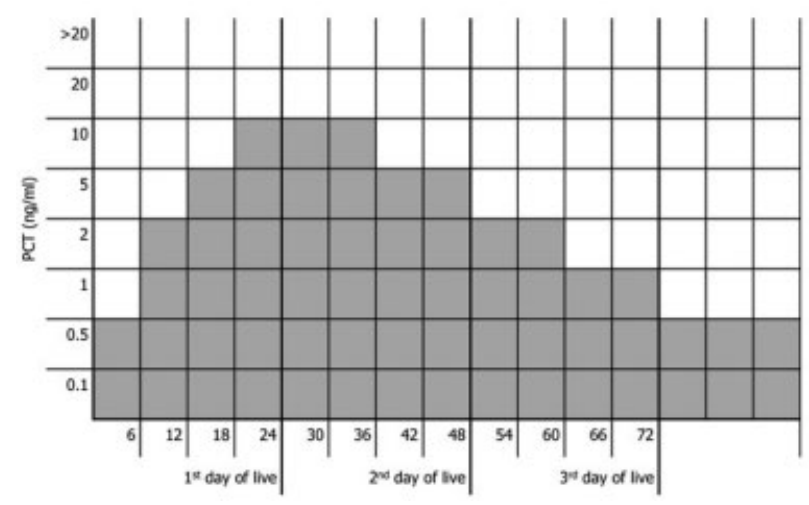

Fig. 1 Normal age-adapted PCT ranges. ${ }^{38}$ Gray boxes = age-adapted normal range. $\mathrm{PCT}$, procalcitonin. Reprinted with permission from Stocker M, Hop WC, van Rossum AM. Neonatal Procalcitonin Intervention Study (NeoPIns): effect of peocalcitonin-guided decision making on duration of antibiotic therapy in suspected neonatal earlyonset sepsis: s multicenter randomized superiority and non-inferiority intervention study. BMC Pediatr 2010:10:89-96. 
of $95.2 \%$ and a negative predictive value of $96.1 \%$, but at the expense of a lower specificity. ${ }^{46}$ Superiority of PCT over CRP and WBC was confirmed recently for EOS in neonates as well (-Fig. 2). ${ }^{47}$

All studies on severe, invasive bacterial infections in children also report higher sensitivities and specificities of PCT than for CRP. ${ }^{48-52}$ PCT has generally performed better in distinguishing children with bacterial infections from those without. With specific regard to separating sepsis from SIRS, multiple studies have demonstrated the diagnostic superiority of PCT. ${ }^{53-57}$ Three studies are of particular interest. Simon et al measured PCT and CRP levels in 64 children who developed SIRS and compared values between those with a posteriori confirmation of infection and those without. Those with confirmed infection (sepsis) had significantly higher PCT values than those without (SIRS only), but CRP levels did not differ between the two groups. ${ }^{57}$ The AUC for PCT in that study was 0.71 versus 0.65 for CRP. Arkader et al results showed that in children with sepsis, serum PCT concentration was significantly elevated above that of noninfected children with SIRS (AUC: 0.99). In the same setting, however, CRP failed to distinguish the two states (AUC: 0.54 ). ${ }^{53}$ The third study is by Rey et al. ${ }^{56}$ In a group of 359 critically ill children, they showed that PCT was superior to CRP in distinguishing six classes of patients: those without SIRS or sepsis, those with SIRS alone, those with local infection, those with sepsis, those with severe sepsis, and those with septic shock. PCT levels increased significantly with the severity of illness (AUC 0.91), whereas CRP failed to mirror the trend as dramatically (AUC: 0.75). ${ }^{56}$

A minority of studies evaluating both PCT and CRP in sepsis have shown that while PCT is a good diagnostic marker for sepsis, it was not statistically more accurate than CRP. $^{39,48,58}$ Contrary to these results, the study by Galetto-

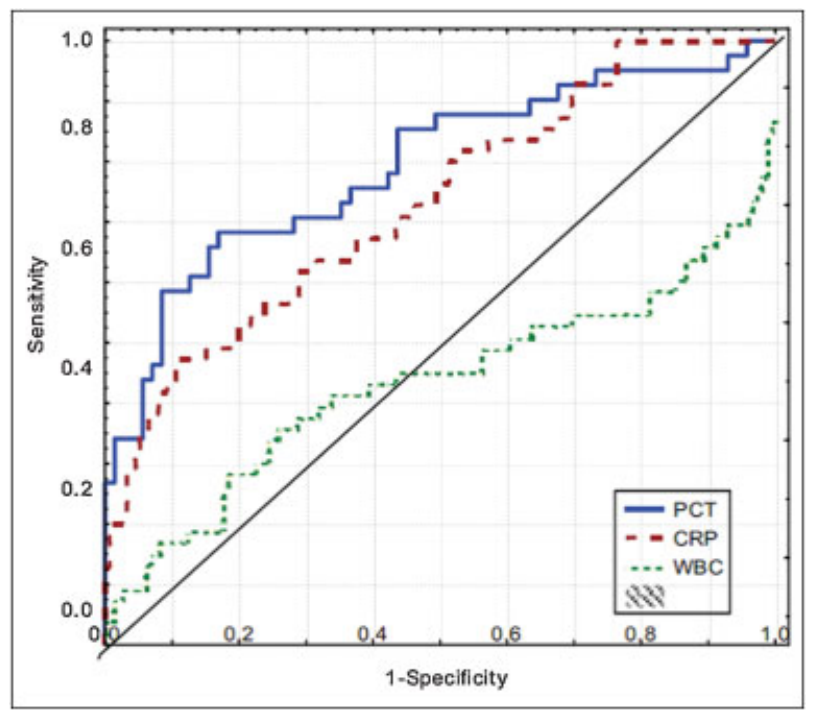

Fig. 2 Receiver operating characteristic curve of PCT, CRP, and WBC count used for diagnosis of early onset neonatal sepsis. $P C T$, procalcitonin; CRP, C-reactive protein; WBC, white blood cells. ${ }^{47}$ (Reprinted with permission from Kordek et al. ${ }^{47}$ )
Lacour et al in 2001 found that PCT was the single most sensitive test. ${ }^{59}$ While a CRP cutoff of $40 \mathrm{mg} / \mathrm{dL}$ was highly sensitive (89\%) and fairly specific (75\%), a PCT cutoff of $0.9 \mathrm{ng} / \mathrm{mL}$ was more sensitive and specific, $93 \%$ and $78 \%$, respectively. When PCT and CRP were combined, a sensitivity of $96 \%$ was achieved, but specificity dropped to $67 \%{ }^{59}$ Galetto-Lacour et al performed a prospective study in 2003 confirming the superiority of PCT. ${ }^{60}$ One hundred and ten children aged 7 days to 36 months presenting to a pediatric emergency department with fever $>38^{\circ} \mathrm{C}$ were enrolled. Ninety-nine children were ultimately analyzed, 29 of whom were diagnosed with SBI. A PCT cutoff of $0.5 \mathrm{ng} / \mathrm{mL}$ resulted in a sensitivity of $93 \%$ and specificity of $74 \%$, similar to the author's previous findings. CRP was even less sensitive (52\%) and specific (74\%) than before for the proposed optimum cutoff of $40 \mathrm{mg} / \mathrm{L}$.

In a study by Andreola et al, subjects were heterogeneous noncritically ill pediatric population presenting in the Emergency Department. ${ }^{61}$ Approximately $50 \%$ of the children were discharged at home. In this population, PCT and CRP were the only factors predictive of SBI and displayed similar diagnostic accuracy. Moreover, PCT was slightly more specific and CRP fairly more sensitive, when considered at their best statistical cutoff values ( $0.8 \mathrm{ng} / \mathrm{L}$ and $32 \mathrm{mg} / \mathrm{L}$, respectively, based on the ROC analysis), in detecting SBI. When PCT and CRP were combined using their best cutoffs, a slightly better screening profile for ruling out SBI was provided (sensitivity of 92.6\%) at the expense of a decrease in specificity (69.8\%). On studying only infants aged less than 3 months, they did not find differences in the AUCs for PCT and CRP with respect to the overall group of patients. ${ }^{61}$ Usefulness of PCT and CRP as predicators of bacterial infections in febrile children aged 1 to 36 months admitted to the pediatric emergency department and subsequently hospitalized was evaluated in a multicenter study by FernandezLopez et al. ${ }^{49}$ Four hundred and forty-five children were enrolled at nine pediatric emergency departments. Eighty children were diagnosed with "localized" bacterial infections, whereas 150 patients were diagnosed with "invasive" bacterial infections. The authors found PCT to be the best predictor of bacterial infection with a sensitivity of $65.5 \%$ and a specificity of $94.3 \%$ for an optimum cutoff of $0.53 \mathrm{ng} / \mathrm{mL}$. CRP (> $27.5 \mathrm{mg} / \mathrm{L}$ ) alone was less sensitive (63.5\%) and less specific (84.2\%). When used to distinguish those children with invasive bacterial disease only, PCT $\geq 0.59 \mathrm{ng} / \mathrm{mL}$ had a sensitivity of $91.3 \%$ and a specificity of $93.5 \%$, much better than the $78 \%$ and $75 \%$ noted with CRP (27.5 mg/L), respectively.

One of the largest studies on PCT was that of Gendrel et al. ${ }^{21}$ The authors examined the sera of 1,500 children aged 1 month to 15 years who were hospitalized after admission to the emergency department with fever $>38.5^{\circ} \mathrm{C}$. Using final diagnosis, they assigned children to three different groups: invasive bacterial infections $(n=46)$, localized bacterial infections $(n=78)$, and lastly viral infections $(n=236)$. Invasive bacterial infections included diagnoses of septicemia and meningitis. The authors found a statistically significant difference between the PCT levels of the different 
groups. The mean PCT level in the group with invasive bacterial infection was $45.9 \mathrm{ng} / \mathrm{mL}$, but it was only 4.2 and $0.4 \mathrm{ng} / \mathrm{mL}$ in the group with localized bacterial infections and viral infections groups, respectively. Analysis of an ROC curve confirmed that PCT was the most useful test, with an AUC of 0.94 versus 0.89 for CRP $(p<0.0001)$. An optimal cutoff of $1 \mathrm{ng} / \mathrm{mL}$ was calculated by the authors for distinguishing bacterial from viral infections. This cutoff had a sensitivity of $83 \%$ and a specificity of $93 \%$. When differentiating only between invasive bacterial infection and other infections, a PCT cutoff of $2 \mathrm{ng} / \mathrm{mL}$ had 96\% sensitivity and $87 \%$ specificity. $^{21}$

The highest combination of sensitivity and specificity was reported by Carrol et al. ${ }^{51}$ Their study, however, was restricted to those with suspected pediatric meningococcal disease (MCD). The authors found that PCT was the most sensitive test: a cutoff value of $2 \mathrm{ng} / \mathrm{mL}$ was $94 \%$ sensitive and 93\% specific for differentiating children with MCD. The broader applicability of the results of this study is difficult to extrapolate because the selected population included only children at high clinical suspicion of MCD.

A recent meta-analysis accounting for 3,244 sepsis patients demonstrated that PCT is a helpful biomarker for early diagnosis of sepsis in critically ill patients. Nevertheless, the results of the test must be interpreted carefully in the context of medical history, physical examination, and microbiological assessment because the studies had shown substantial heterogeneity. ${ }^{62}$

\section{Conclusion}

A battery of tests including the complete blood count, leukocyte differential counting for evidence of a myeloid left shift, erythrocyte sedimentation rate, CRP, PCT, ILs, and microbiological cultures are used in the laboratory evaluation of patients with suspected infection or sepsis. However, it is still not always possible to accurately predict the presence of bacterial infection on the basis of clinical appearance and those laboratory tests. Therefore, the investigation of new and better biomarkers is challenging and ongoing. ${ }^{63}$

\section{References}

1 Brent AJ, Lakhanpaul M, Thompson M, et al. Risk score to stratify children with suspected serious bacterial infection: observational cohort study. Arch Dis Child 2011;96(04):361-367

2 Dellinger RP, Levy MM, Carlet JM, et al; International Surviving Sepsis Campaign Guidelines Committee; American Association of Critical-Care Nurses; American College of Chest Physicians; American College of Emergency Physicians; Canadian Critical Care Society; European Society of Clinical Microbiology and Infectious Diseases; European Society of Intensive Care Medicine; European Respiratory Society; International Sepsis Forum; Japanese Association for Acute Medicine; Japanese Society of Intensive Care Medicine; Society of Critical Care Medicine; Society of Hospital Medicine; Surgical Infection Society; World Federation of Societies of Intensive and Critical Care Medicine. Surviving Sepsis Campaign: international guidelines for manage- ment of severe sepsis and septic shock: 2008. Crit Care Med 2008; 36(01):296-327

3 Thompson MJ, Ninis N, Perera R, et al. Clinical recognition of meningococcal disease in children and adolescents. Lancet 2006; 367(9508):397-403

$4 \mathrm{Ng}$ PC, Lam HS. Diagnostic markers for neonatal sepsis. Curr Opin Pediatr 2006;18(02):125-131

5 Atkinson A, Colburn W, DeGruttola V, et al; Biomarkers Definitions Working Group. Biomarkers and surrogate endpoints: preferred definitions and conceptual framework. Clin Pharmacol Ther $2001 ; 69(03): 89-95$

6 Marshall JC, Reinhart K; International Sepsis Forum. Biomarkers of sepsis. Crit Care Med 2009;37(07):2290-2298

7 Kaplan JM, Wong HR. Biomarker discovery and development in pediatric critical care medicine. Pediatr Crit Care Med 2011;12 (02):165-173

8 Jaye DL, Waites KB. Clinical applications of C-reactive protein in pediatrics. Pediatr Infect Dis J 1997;16(08):735-746, quiz 746747

9 Du Clos TW. Function of C-reactive protein. Ann Med 2000;32 (04):274-278

10 Jardine L, Davies MW, Faoagali J. Incubation time required for neonatal blood cultures to become positive. J Paediatr Child Health 2006;42(12):797-802

11 Hofer N, Zacharias E, Müller W, Resch B. An update on the use of C-reactive protein in early-onset neonatal sepsis: current insights and new tasks. Neonatology 2012;102(01):25-36

12 Couto RC, Barbosa JA, Pedrosa TM, Biscione FM. C-reactive protein-guided approach may shorten length of antimicrobial treatment of culture-proven late-onset sepsis: an intervention study. Braz J Infect Dis 2007;11(02):240-245

13 Franz AR, Kron M, Pohlandt F, Steinbach G. Comparison of procalcitonin with interleukin $8, \mathrm{C}$-reactive protein and differential white blood cell count for the early diagnosis of bacterial infections in newborn infants. Pediatr Infect Dis J 1999;18(08): 666-671

14 Haque KN. Defining common infections in children and neonates. J Hosp Infect 2007;65(Suppl 2):110-114

15 Philip AG, Mills PC. Use of C-reactive protein in minimizing antibiotic exposure: experience with infants initially admitted to a well-baby nursery. Pediatrics 2000;106(01):E4. Doi:

16 Franz AR, Steinbach G, Kron M, Pohlandt F. Reduction of unnecessary antibiotic therapy in newborn infants using interleukin-8 and C-reactive protein as markers of bacterial infections. Pediatrics 1999;104(3 Pt 1):447-453

17 Benitz WE, Han MY, Madan A, Ramachandra P. Serial serum C-reactive protein levels in the diagnosis of neonatal infection. Pediatrics 1998;102(04):E41

18 Pulliam PN, Attia MW, Cronan KM. C-reactive protein in febrile children 1 to 36 months of age with clinically undetectable serious bacterial infection. Pediatrics 2001;108(06): 1275-1279

19 Bilavsky E, Yarden-Bilavsky H, Ashkenazi S, Amir J. C-reactive protein as a marker of serious bacterial infections in hospitalized febrile infants. Acta Paediatr 2009;98(11):1776-1780

20 Olaciregui I, Hernández U, Muñoz JA, Emparanza JI, Landa JJ. Markers that predict serious bacterial infection in infants under 3 months of age presenting with fever of unknown origin. Arch Dis Child 2009;94(07):501-505

21 Gendrel D, Raymond J, Coste J, et al. Comparison of procalcitonin with C-reactive protein, interleukin 6 and interferon-alpha for differentiation of bacterial vs. viral infections. Pediatr Infect Dis J 1999;18(10):875-881

22 Póvoa P, Coelho L, Almeida E, et al. C-reactive protein as a marker of infection in critically ill patients. Clin Microbiol Infect 2005;11 (02):101-108 
23 Schmit X, Vincent JL. The time course of blood C-reactive protein concentrations in relation to the response to initial antimicrobial therapy in patients with sepsis. Infection 2008;36(03):213-219

24 Sanders S, Barnett A, Correa-Velez I, Coulthard M, Doust J. Systematic review of the diagnostic accuracy of C-reactive protein to detect bacterial infection in nonhospitalized infants and children with fever. J Pediatr 2008;153(04):570-574

25 Becker KL, Snider R, Nylen ES. Procalcitonin assay in systemic inflammation, infection, and sepsis: clinical utility and limitations. Crit Care Med 2008;36(03):941-952

26 Christ-Crain M, Jaccard-Stolz D, Bingisser R, et al. Effect of procalcitonin-guided treatment on antibiotic use and outcome in lower respiratory tract infections: cluster-randomised, singleblinded intervention trial. Lancet 2004;363(9409):600-607

27 Christ-Crain M, Stolz D, Bingisser R, et al. Procalcitonin guidance of antibiotic therapy in community-acquired pneumonia: a randomized trial. Am J Respir Crit Care Med 2006;174(01):84-93

28 Stolz D, Christ-Crain M, Bingisser R, et al. Antibiotic treatment of exacerbations of COPD: a randomized, controlled trial comparing procalcitonin-guidance with standard therapy. Chest 2007;131 (01):9-19

29 Nobre V, Harbarth S, Graf JD, Rohner P, Pugin J. Use of procalcitonin to shorten antibiotic treatment duration in septic patients: a randomized trial. Am J Respir Crit Care Med 2008;177(05): 498-505

30 Müller B, White JC, Nylén ES, Snider RH, Becker KL, Habener JF. Ubiquitous expression of the calcitonin-i gene in multiple tissues in response to sepsis. J Clin Endocrinol Metab 2001;86(01):396-404

31 Tang BM, Eslick GD, Craig JC, McLean AS. Accuracy of procalcitonin for sepsis diagnosis in critically ill patients: systematic review and meta-analysis. Lancet Infect Dis 2007;7(03):210-217

32 Assicot M, Gendrel D, Carsin H, Raymond J, Guilbaud J, Bohuon C. High serum procalcitonin concentrations in patients with sepsis and infection. Lancet 1993;341(8844):515-518

33 Müller B, Becker KL, Schächinger H, et al. Calcitonin precursors are reliable markers of sepsis in a medical intensive care unit. Crit Care Med 2000;28(04):977-983

34 Nylen ES, O'Neill W, Jordan MH, et al. Serum procalcitonin as an index of inhalation injury in burns. Horm Metab Res 1992;24(09): 439-443

35 Whang KT, Steinwald PM, White JC, et al. Serum calcitonin precursors in sepsis and systemic inflammation. J Clin Endocrinol Metab 1998;83(09):3296-3301

36 Nakamura A, Wada H, Ikejiri M, et al. Efficacy of procalcitonin in the early diagnosis of bacterial infections in a critical care unit Shock 2009;31(06):586-591

37 Luzzani A, Polati E, Dorizzi R, Rungatscher A, Pavan R, Merlini A. Comparison of procalcitonin and $C$-reactive protein as markers of sepsis. Crit Care Med 2003;31(06):1737-1741

38 Stocker M, Fontana M, El Helou S, Wegscheider K, Berger TM. Use of procalcitonin-guided decision-making to shorten antibiotic therapy in suspected neonatal early-onset sepsis: prospective randomized intervention trial. Neonatology 2010;97(02):165-174

39 Groselj-Grenc M, Ihan A, Pavcnik-Arnol M, Kopitar AN, GmeinerStopar T, Derganc M. Neutrophil and monocyte CD64 indexes, lipopolysaccharide-binding protein, procalcitonin and C-reactive protein in sepsis of critically ill neonates and children. Intensive Care Med 2009;35(11):1950-1958

40 Turner D, Hammerman C, Rudensky B, Schlesinger Y, Schimmel MS. The role of procalcitonin as a predictor of nosocomial sepsis in preterm infants. Acta Paediatr 2006;95(12):1571-1576

41 Resch B, Gusenleitner W, Müller WD. Procalcitonin and interleukin-6 in the diagnosis of early-onset sepsis of the neonate. Acta Paediatr 2003;92(02):243-245

42 Chiesa C, Panero A, Rossi N, et al. Reliability of procalcitonin concentrations for the diagnosis of sepsis in critically ill neonates. Clin Infect Dis 1998;26(03):664-672
43 Chiesa C, Pellegrini G, Panero A, et al. C-reactive protein, interleukin-6, and procalcitonin in the immediate postnatal period: influence of illness severity, risk status, antenatal and perinatal complications, and infection. Clin Chem 2003;49(01):60-68

44 Bonac B, Derganc M, Wraber B, Hojker S. Interleukin-8 and procalcitonin in early diagnosis of early severe bacterial infection in critically ill neonates. Pflugers Arch 2000;440(5, Suppl):R72-R74

45 Lapillonne A, Basson E, Monneret G, Bienvenu J, Salle BL. Lack of specificity of procalcitonin for sepsis diagnosis in premature infants. Lancet 1998;351(9110):1211-1212

46 Maniaci V, Dauber A, Weiss S, Nylen E, Becker KL, Bachur R. Procalcitonin in young febrile infants for the detection of serious bacterial infections. Pediatrics 2008;122(04):701-710

47 Kordek A, Torbé A, Tousty J, et al. The determination of procalcitonin concentration in early-onset neonatal infection: a valuable test regardless of prenatal antibiotic therapy. Clin Pediatr (Phila) 2017;56(04):333-340

48 Enguix A, Rey C, Concha A, Medina A, Coto D, Diéguez MA. Comparison of procalcitonin with C-reactive protein and serum amyloid for the early diagnosis of bacterial sepsis in critically ill neonates and children. Intensive Care Med 2001;27(01):211-215

49 Fernández Lopez A, Luaces Cubells C, García García JJ, Fernández Pou J; Spanish Society of Pediatric Emergencies. Procalcitonin in pediatric emergency departments for the early diagnosis of invasive bacterial infections in febrile infants: results of a multicenter study and utility of a rapid qualitative test for this marker Pediatr Infect Dis J 2003;22(10):895-903

50 Prat C, Domínguez J, Rodrigo C, et al. Use of quantitative and semiquantitative procalcitonin measurements to identify children with sepsis and meningitis. Eur J Clin Microbiol Infect Dis 2004;23(02):136-138

51 Carrol ED, Newland P, Riordan FA, Thomson AP, Curtis N, Hart CA. Procalcitonin as a diagnostic marker of meningococcal disease in children presenting with fever and a rash. Arch Dis Child 2002;86 (04):282-285

52 Hatherill M, Tibby SM, Sykes K, Turner C, Murdoch IA. Diagnostic markers of infection: comparison of procalcitonin with $C$ reactive protein and leucocyte count. Arch Dis Child 1999;81(05): 417-421

53 Arkader R, Troster EJ, Lopes MR, et al. Procalcitonin does discriminate between sepsis and systemic inflammatory response syndrome. Arch Dis Child 2006;91(02):117-120

54 Casado-Flores J, Blanco-Quirós A, Asensio J, Arranz E, Garrote JA Nieto M. Serum procalcitonin in children with suspected sepsis: a comparison with C-reactive protein and neutrophil count. Pediatr Crit Care Med 2003;4(02):190-195

55 Fioretto JR, Martin JG, Kurokawa CS, et al. Comparison between procalcitonin and C-reactive protein for early diagnosis of children with sepsis or septic shock. Inflamm Res 2010;59(08): 581-586

56 Rey C, Los Arcos M, Concha A, et al. Procalcitonin and C-reactive protein as markers of systemic inflammatory response syndrome severity in critically ill children. Intensive Care Med 2007;33(03): 477-484

57 Simon L, Saint-Louis P, Amre DK, Lacroix J, Gauvin F. Procalcitonin and C-reactive protein as markers of bacterial infection in critically ill children at onset of systemic inflammatory response syndrome. Pediatr Crit Care Med 2008;9(04):407-413

58 Carrol ED, Newland P, Thomson AP, Hart CA. Prognostic value of procalcitonin in children with meningococcal sepsis. Crit Care Med 2005;33(01):224-225

59 Lacour AG, Gervaix A, Zamora SA, et al. Procalcitonin, IL-6, IL-8, IL1 receptor antagonist and C-reactive protein as identificators of serious bacterial infections in children with fever without localising signs. Eur J Pediatr 2001;160(02):95-100

60 Galetto-Lacour A, Zamora SA, Gervaix A. Bedside procalcitonin and C-reactive protein tests in children with fever without 
localizing signs of infection seen in a referral center. Pediatrics 2003;112(05):1054-1060

61 Andreola B, Bressan S, Callegaro S, Liverani A, Plebani M, Da Dalt L. Procalcitonin and C-reactive protein as diagnostic markers of severe bacterial infections in febrile infants and children in the emergency department. Pediatr Infect Dis J 2007;26(08):672-677
62 Wacker C, Prkno A, Brunkhorst FM, Schlattmann P. Procalcitonin as a diagnostic marker for sepsis: a systematic review and metaanalysis. Lancet Infect Dis 2013;13(05):426-435

63 Markic J, Jeroncic A, Polancec D, et al. CD15s is a potential biomarker of serious bacterial infection in infants admitted to hospital. Eur J Pediatr 2013;172(10):1363-1369 